\title{
THE EFFECTIVENESS OF TWO-STAY TWO STRAY IN ENHANCING STUDENTS' SPEAKING ABILITY
}

\author{
Andri Iswanto $^{1}$, Sela Anugrah ${ }^{2}$, Trisnendri Syahrial ${ }^{3}$ \\ ${ }^{1}$ IKIP Siliwangi \\ ${ }^{2}$ IKIP Siliwangi \\ ${ }^{3}$ IKIP Siliwangi \\ ${ }^{1}$ Andriiswanto94@gmail.com, ${ }^{2}$ Sela94.anugrah1@ gmail.com, ${ }^{3}$ tugastrisnendri@gmail.com
}

\begin{abstract}
The study is aimed at describing the effectiveness of two stay and two stray in enhancing students'speaking ability. The paper is derived from the research result conducted among 30 students of SMK Budi Bakti Utama Padalarang. Classroom action research design with 2 cycles was applied to encourage students' speaking skill. Observation checklist, fieldnote and speaking test instruments were used to catch on students' progress (reflection and evaluation). Observation was finished to see how clear the strategy was understood and performed by the leraners. Fieldnote aimed at jotting down success and restraint of the strategy usage and tes instrument was managed to assess the grading and scoring development whole the first and second cycles. Reflecting and evaluating were organized at the end of every cycle. Based on observation and fieldnote that the students'participation were getting upgraded in every cycle. Besides, the average score and grade at the end of 2 cycles were getting improved. Mean score of cycle 1 was 59.00, and cycle 2 was 65.00 . It could be concluded that two stay and two stray strategy boosted speaking ability for English department students of SMK Budi Bakti Utama Padalarang in academic year 2018/2019.
\end{abstract}

Keywords: Two Stay Two Stray, Speaking Skill, Car

\section{INTRODUCTION}

The process of learning is an effort to give knowledge or information to students. An existing knowledge and information in the students' selves will be related and then they will be used as the basis for making conclusions regarding a trouble. All those things will be directed toward the changes in the students' behaviors. The change will not only be in the increment of knowledge by also in the form of their skills, behaviors, comprehension, interests, and selfimprovement. Thus, the process of learning implicate activities of minds and bodies that will make changes in the skills that students possess from the teaching and learning process which in turn has to produce a maximum outcome. According to Mudjiono (2010) "Learning outcome is the peak of learning process". The learning outcome occurs because of the teacher's evaluation and basically covers cognitive, affective, psychomotor aspects.

A study can be considered as successful if the students show great activities. So far, students in SMK Budi Bakti Utama and others vocational high schools only partly come to schools to listen to the teachers' explanation and then do their tasks back at home and so on. Most students are inactive in classrooms. Therefore, most students still memorize the material and a lot still feels pressured with the learning process. Students must be the main actors in the class but the implemented learning model still does not involve the students maximally. This condition then becomes a constraint for a learning medium that creates a positive change. 
In order to create a learning that is suitable for the hoped purpose in the form of deep comprehension, we need the correct approach. Teachers have a great role in this matter to create a learning environment where the students are interested in the taught material. The reality out on the field shows that the process of teaching and learning still uses learning model of lecturing that causes a lot of influences toward the outcome. Based on some theories and experiences, teachers should prepare everything before conducting the study to prepare a good and systematic learning situation.

One of the efforts done by teachers is the usage of a learning method or model that is suitable for the condition and situation of a class. A number of students influence the usage of learning model that will be used. To achieve the goal of the learning material, teachers need to choose an appropriate learning model to attract the students' interest in the subjects, such as cooperative learning model.

The researcher wants to do a research regarding the cooperative learning model of Two Stay Two Stray (TSTS) dan Co-op Co-op that is performed in the crafts and entrepreneurship subject to make an active and fun learning situation that will improve the outcome. TSTS learning is one model of the types of cooperative learning that gives chance to groups to distribute the outcome and information to any groups. According to Sulisworo \& Suryani (Sulisworo, 2014) by using TSTS structure, learners will get used to respecting others' opinions and they can express their opinions to others and they can increase their confidence in expressing ideas. Several studies about the solicitation of Two Stay Two Stray strategy has been done previously. Strategy of Two Stay Two Stray is one of the strategies in cooperative learning. This Two Stay Two Stray teaching and learning strategy was promoted by Spencer Kagan in the book Nation. The strategy can be used in all those subjects and the learners in all levels of age. Lie (2010) suggested that the structure of the Two Stay Two Stray offers an opportunity for the group to share results and information with other groups.

Step-by-step of learning implementation in Two Stay Two Stray strategy is as follows: (1) students work together in groups of four; (2) after finishing the discussion, two people from each group will leave the group and visit to the other group, (3) two people who still stay in a group are in charge to divide the result of group work and share information to every guest who visited the group, (4) guests ask for permission to go back to their own groups and report the findings that they have got from other groups, and (5) group match and discuss the results of their work.

Seeing that there are several steps in Two Stay Two Stray strategy above, it will help the tenth grade of SMK Budi Bakti Utama in academic year 2018/2019 to resolve problems or constraints found in communicating the idea in speaking. According to Brown (2007: 4) in Parmawati (2018) defines speaking as an interactive process of constructing meaning that involves producing, receiving and processing speech of sounds as the main instrument.

Darmadi (2015) in Parmawati and Inayah (2019) defines speaking as a productive skill that can be observed directly and empirically. But, in reality the students have difficulty in communicating their ideas in speaking (in the theme of subject is descriptive text). This difficulty can be solved by putting them in a group of four people. It consists of four people in different levels of fluency. One of them is a student in an expert or high of fluency who can help three other students to be fluent in speaking. This is very helpful in terms of both in psychological aspect and material aspect that they want to say. They will be more flexible in speaking and a lot of ideas arise because one of them will facilitate the idea. This partnership will certainly help them in build up courage and confidence.

According to Sudrajat (2011), referring to the idea of L de Fink in an article entitled Active Learning. Active learning consists of two main components, those are the main elements which 
comprises the element of experience (experience) including activities to do (doing), observation activities (observing) and the dialogue which comprises the dialogue with the self and the dialogue with others (with self).

\section{METHOD}

The method used in conducting this research is Classroom Action Research. Acording to Julian Hermida (2001) in fitri (Fitri, 2016) Classroom Action Research is a method of finding out what works best in your own classroom so that you could improve students in learning process. There are many ways to improve knowledge about teaching. Most teachers practice personal reflection on teaching, others conduct formal empirical studies on teaching and learning.

In addition, D. Hopkins in his book (Hopkins, n.d.) the title A Teacher's Guide to Classroom Research action research is a from of self-reflektif inquiry undertaken by companions in a social (including education) situation in order to correct the rationality and of (a) their own social or educational practices justice (b) their understanding of these exercises, and (c) the situastions in which practices are implemented.

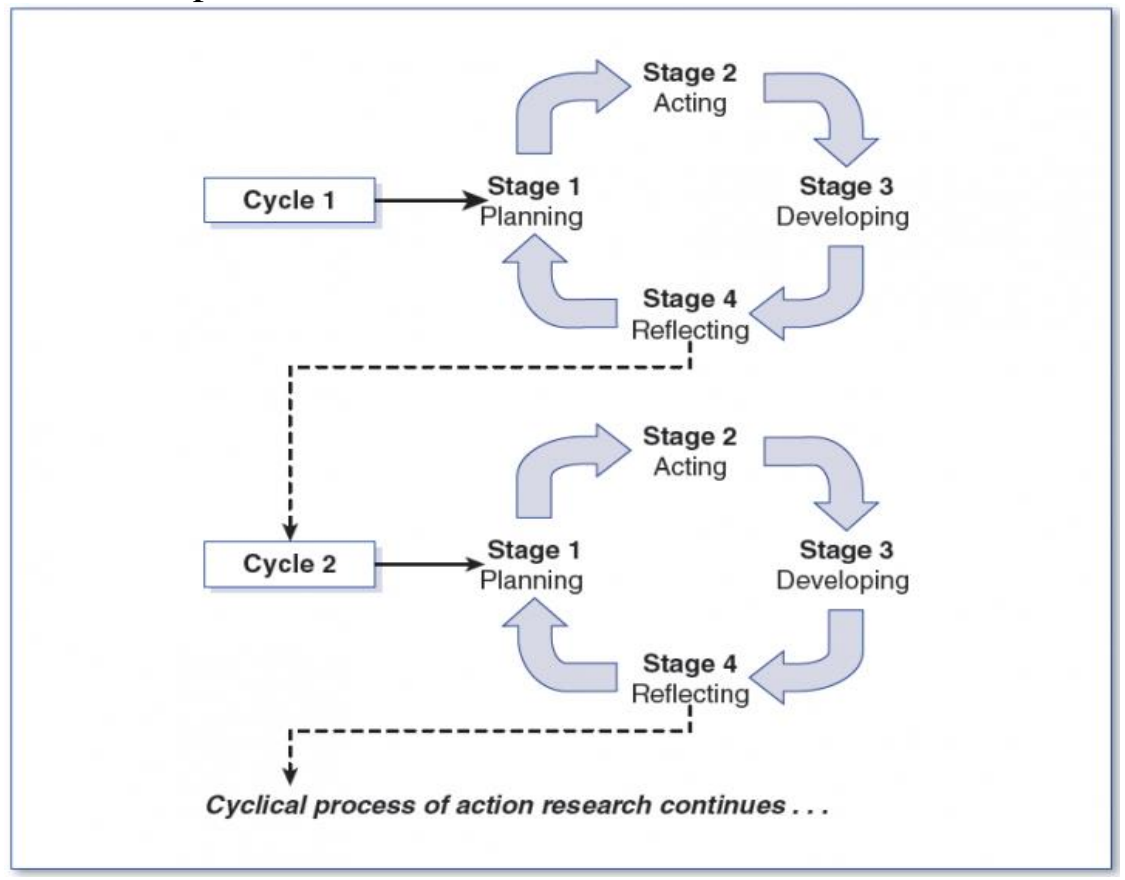

(Adapted from Mertler and Charles, 2011)

Figure 1 Cycling Process of Classroom action Research

There are four steps of typical actions research model; they are divided into certain cycles of action starting from stage 1 (planning), stages 2 (acting), stage 3 (observing), and stage 4 (reflecting). The cycle stopped if the students had reached the target score stated in school KKM (Kriteria Ketuntasan Minimal), It is 70 as the minimum scores to English subject at Senior High School in Budi Bakti Utama Padalarang. In other side, if the students cannot reach the target scores which was stated in school KKM, this cyclical process of action research must be continued.

The research brought into two cycles which each cycle contained pre-test and post-test. The subject study was the first semester learners of senior high school level which consisted of 30 students. There were in total seven meetings covered on those two cycles; three meetings were for tests, and the other four meetings were for doing treatment. The treatment was teaching speaking, especially discussion, with the application of Two-Stay Two-Stray method. 
The instruments used in this research were observation, field notes and tests. The tests were used to test the learners on pre-test, post-test 1 and post-test 2 . The tests given consisted of 20 items in the form of fill in the blank questions.

\section{RESULTS AND DISCUSSION}

\section{Results}

The research carried on ten grade of senior high school level for seven meetings. The seven meetings were categorized into two cycles. The result of each cycle would be organized on four steps of CAR, namely: (1) planning, (2) acting, (3) observing, and (4) reflecting.

\section{Cycle I.}

from the results in observation, classically only $50 \%$ of students were able to speak with the correct use of vocabulary, correct pronunciation and 60\% students used correct grammar. Further, the results obtained from field note showed that only $50 \%$ of students could speak fluently. While the students who were actively asking only a few students. Students who could use the appropriate vocabulary were only about 55\%. The students who performed correct pronunciation were only a third of them. The latter, appropriate used of grammar was only $50 \%$. Average test results of students' speaking skill was 59 (score 1-100).

Table 1. Meetings in cycle I

\begin{tabular}{|c|c|c|}
\hline & Acting & Observing \\
\hline Meeting & Topic & Activity \\
\hline 1 & $\begin{array}{l}\text { Pre-test: } \\
\text { Descriptive text. }\end{array}$ & $\begin{array}{l}\text { In the first meeting, the researcher gave } 1 \text { picture to } \\
\text { describe it. }\end{array}$ \\
\hline 2 & $\begin{array}{l}\text { Treatment } 1: \text { Descriptive } \\
\text { text }\end{array}$ & $\begin{array}{l}\text { They discuss for descriptive text using Two-Stay } \\
\text { Two Stray Technique. The researchers gave theme } \\
\text { animal to discuss and students describe it. }\end{array}$ \\
\hline 3 & $\begin{array}{l}\text { Treatment 2: } \\
\text { Descriptive text }\end{array}$ & $\begin{array}{l}\text { They were repeat the same things but the student } \\
\text { arrangement } 1 \text { sentence to describe it. }\end{array}$ \\
\hline 4 & Post test : & $\begin{array}{l}\text { In last meeting, the researcher conducted a post- } \\
\text { test with gave the students a picture to describe, } \\
\text { but the picture more complex than previous. }\end{array}$ \\
\hline
\end{tabular}

The last session for cycle 1 reflects. In this step, the researcher made some implications from the observations found whole the teaching and learning process. It start from pre-test. The students admitted that the test aid was surprising because of their very limited vocabulary plus a lack of insight into the topics. However, their willingness to test is still there. The test is finished well although there are some students who did unsatisfy. The average pre-test scores is only 41.87. This score is considered low, while the minimum scores to pass is 3.0. In addition, low ability in students is due to lack of vocabulary mastering so that was difficult to decribe the topic.

Many students knows already about the topics they will explain, but almost some students had a basic vocabulary. Whole the treatment, 1 and 2, the researcher looks at the way of students describe the topic each group represents its group using the Two-Stay Two-Stray technique. On the first treatment, the students looked confused. They were not sure for the answer. They still need teacher to guidance them just about everything in every step. The students still felt uncomfortable when described using the technique as they are in the lead to dig out their 
vocabulary.They were hesitant when expressing their ideas, and it becomes a barrier to classroom action research.

However, at the end of treatment 2, researchers noticed that work enjoyment began to emerge. They began to dare to express the idea in describing the topic. That was followed by an increase in post-test score reaching 59.62. From that treatment in cycle 1, we could draw the conclusion that the positive and negative results found whole the lessons. The positive result was students begin to show their vocabulary development by believing speaking when describing, and the negative result is the noise and disturbance of those discussing the material. Revisions must be made to improve the quality of their learning as well as their average value. Therefore, cycle II is $\mathrm{d}$ to continue the research.

\section{Cycle II.}

The result of observation has shown that all groups can send two members to another group. Two people who stayed in a group they have attended also shared the results of their group quite smoothly. Two students in this cycle have been involved. There was a little progress, where in cycle 1 only one person who told the story from beginning till the end. This happened in almost all groups. At the time the students came back to the group to share the results of his or her visit, both were already delivered story telling in this occasion. By judging from the activity, individually and classically significant change could be seen. Overall Students have been already actively talking although the quality was still not high enough. While the results obtained from field note shown that only $65 \%$ of students speak fluently. Whereas, students who have already been asking almost half. Students who could use vocabulary appropriately was about $70 \%$. The students who performed correct pronunciation were almost $70 \%$. The last, students who used correct grammar was $65 \%$. The results of this test cycle average were 65.00. This fact proved the success of Two Stay Two Stray strategy's implementation. Thus, it indicated that Two Stay Two Stray strategy can enhance speaking skill of eleventh grade students' of Budi Bakti Utama Padalarang in academic year 2018/2019, as seen in table 2 below:

Table 2.Meetings in cycle II

\begin{tabular}{cll}
\hline Meeting & Acting & Observing \\
\hline 5 & Topic & Treatment 3: \\
Descriptive text & $\begin{array}{l}\text { They discuss about the descriptive text using Talking } \\
\text { Chips Technique. The researchers give theme hero people } \\
\text { to discuss and students gave 1 sentences to describe. }\end{array}$ \\
\hline 6 & $\begin{array}{l}\text { Treatment 4: } \\
\text { Descriptive text }\end{array}$ & $\begin{array}{l}\text { They did the same as with previous meeting discuss about } \\
\text { hero people but the student arrangement 4 sentences to } \\
\text { describe it. }\end{array}$ \\
\hline 7 & Post test: & $\begin{array}{l}\text { In this meeting, the researcher conducted a post-test with } \\
\text { the gave them 1 picture to describe, but the picture more } \\
\text { complicated than the fourth meeting. }\end{array}$ \\
\hline
\end{tabular}

Reflecting of the observation done would be discussed in this section. There were much improvement in every meeting. The improvement were as follows: (1) their score on post-test 2 was increased. From 45.87 for pre-test, it was improved to be 60.62 . and for the post-test 2, their score became 75.25, and (2) their quality of learning shown from their attitude and behaviour during joining the lesson. 
The detail result of score of the test can be seen on table 3 below.

Table 3.Improvement on students' score of the tests.

\begin{tabular}{cccc}
\hline & Pre-test & Post-test 1 & Post-test 2 \\
\hline Minimum score & 37 & 47 & 68 \\
\hline Maximal score & 64 & 74 & 90 \\
\hline Mean score & 45.87 & 60.62 & 75.25 \\
\hline
\end{tabular}

\section{Discussion}

This research begins with the aim of improving the ability in speaking and vocabulary by using Two-Stay Two-Stray technique. Through two cycles, three tests and four treatments, the process of teaching and learning were carried out and run so well on the second semester students of Senior high school level. As it is shown on the data above that the improvement of score has reached the target which is 6.0 , while the improvement of attitude and behavior has reached the researchers satisfaction. Therefore, the research will not be continued to cycle III. The use of this method true can improve the students speaking ability to their vocabulary quantitatively, through the improvement of score, and qualitatively, through the improvement of attitude and behavior.

As stated before, two-stay two-stray helps students develop their speaking and improving vocabulary of a topic because they discuss it with their friend in group. It makes them feel free to talk about everything they want describe with the topic. By doing that activity their ability to speak, and improve their vocabulary. Besides, setting the students for discuss in group using two-stay two-stray gives more opportunities to the students on exploring themselves for speak and improve their vocabulary.

\section{CONCLUSION}

The implementation of two stay two stray strategies in speaking for discussion subject at the eleventh grade students' of Budi Bakti Utama Padalarang in academic year 2018/2019 can enhance students' speaking skill in five major aspects namely smoothness (fluency), vocabulary (vocabulary), pronunciation ( pronunciation), grammar (grammar) and a thorough understanding (comprehension). It can be seen from the increasing in the average results of tests conducted at the end of the cycle.

The results of this study can also be useful for subjects in other skills such as writing and reading. The implementation of this strategy in the same skill is expected to be implemented to the sample in the same characteristics with this research for maximum results.

\section{ACKNOWLEDGMENTS}

We thank the family, parents, friends and lecturers who have given us support both morally and materially, so that we can complete and publish our journal.

\section{REFERENCES}

Fitri, M. (2016). Iselt-4 2016 Proceedings Of The Fourth International Seminar On English Language And Teaching, 62-67.

Hopkins, D. (N.D.). A Teacher' S Guide To Classroom-Based Research.

Lie., A. (2010). Cooperative Learning Mempraktikkan Cooperative Learning Di Ruang- 
Ruangkelas. Jakrta: Grasindo.

Mudjiono, D. (2010). Belajar Dan Pembelajran. Jakarta: Rineka Cipta.

Parmawati, A. (2018). Using Analytic Teams Technique To Improve Students'speaking Skill. Edulitics (Education, Literature, And Linguistics) Journal, 3(2), 21-25.

Parmawati, A., \& Inayah, R. (2019). Improving Students'speaking Skill Through English Movie In Scope Of Speaking For General Communication. Eltin Journal, Journal of English Language Teaching In Indonesia, 7(2), 43-53.

Sudrajat. (2011). Dasar - Dasar Penelitian Ilmiah. Bandung: Pustaka Setia.

Sulisworo, D. Dan F. S. (2014). The Effective Of Cooperative Learning, Motivation And Informasi Technology Literacy To Achievement. International Journal Of Learning \& Development, 4(2), 58-64. 